\title{
THE APPLICATION OF GROUP INVESTIGATION MODEL IN CIRCULATION LEARNING SYSTEM TO IMPROVE STUDENTS' SCIENCE PROCESS SKILLS AND CRITICAL THINKING ABILITIES
}

\author{
Muhibbuddin $^{1 *}$, Tya Novenda Sari ${ }^{2}$, Khairil $^{3}$, Andi Ulfa Tenri Pada \\ ${ }^{1}$ Dr, SyiahKuala University, Banda Aceh, Indonesia, muhibbuddin@unsyiah.ac.id \\ 2SyiahKuala University, Banda Aceh, Indonesia, novendasaritya@gmail.com \\ ${ }^{3} \mathrm{Dr}$, SyiahKuala University, Banda Aceh, Indonesia, khairilbio@unsyiah.ac.id \\ ${ }^{4} \mathrm{Dr}$, SyiahKuala University, Banda Aceh, Indonesia, andi_ulfa@unsyiah.ac.id \\ ${ }^{*}$ Corresponding Author
}

\begin{abstract}
Science process skills and critical thinking abilities are two things students must have. Some studies show that students are lack of science process skills and critical thinking. Therefore innovation in the learning process through the application of the group investigation model is needed to improve students' science process skills and critical thinking abilities. This research aims to improve students' science process skills and critical thinking abilities through the application of group investigation learning models. This research was conducted using an experimental method with a pretest-posttest control group design. The research subjects were two groups consisting of 58 experimental group students and 68 control group students. Learning in the experimental group is carried out through group investigation model learning, while the control group uses conventional learning models. The parameters measured were an increase in science process skills and critical thinking skills. The science process skills and critical thinking abilities data were analyzed using parametric statistics, namely testing the difference in the two average normalized gain ( $\mathrm{n}$ gain) scores using an independent sample t-test. The results showed a significant difference in the improvement of science process skills and critical thinking of students between the experimental class and the control class. It means that the application of the group investigation learning model contributes both to the improvement of students' science process skills and critical thinking abilities.
\end{abstract}

Keywords: Science process skill, critical thinking ability, group investigation.

\section{INTRODUCTION}

Science process skill is the process of scientific activity. Science process skills are an assimilation of various intellectual skills that are applied to the learning process (Handayani et al., 2016). Students need to practice science process skills so that they have experience and provision in learning that leads to skills development. Science process skills are repetitive skills and start with the most basic skills. Science process skills training for students can be carried out by utilizing practical materials.

In addition to science process skills, students must also have critical thinking abilities that enable students to hypothesize, analyze and synthesize events, and develop new hypotheses and test them according to facts. 
Asking questions is the basis of critical thinking which is the basis of the formation of knowledge taught to students to practice students' skills in the world of work.

Critical thinking is the activity of analyzing ideas in a more specific direction. According to Eggen and Kauchak (2012), critical thinking is the ability of a person to make and conduct an assessment of conclusions based on facts. Nugraha et al. (2017) states that students must have critical thinking abilities so that they can analyze, assess, and reconstruct their thinking to solve problems.

The results of observations at High Schools in Meulaboh show that the students are lacking in critical thinking abilities. Only $33 \%$ of students scored above the minimum completeness criteria while the other $67 \%$ under the criteria. Many students find it difficult to focus on one issue causing them difficulty forming questions that are the basis of the critical thinking process. The low science process skills are caused by learning only focusing on the material without involving students in observing the circulation system.

The use of learning models that can stimulate the improvement of students' critical thinking abilities and science process skills is one way to overcome these problems. One of the innovative learning strategies and following the circulation system material is the group investigation learning model. This model can increase student motivation and productivity when facing various problems of daily life. The group investigation model also encourages students to work and communicate in groups (Johnson et al., 2007). In learning group investigation models students are required to plan, carry out, report, and present investigations. Research on the application of group investigation (Santyasa et al., 2018; Siddiqui, 2013; Suhartono et al., 2019; Parinduri et al., 2017; Tsoi et al., 2004; Linuhung \& Sudarman , 2016; Mitchell et al., 2008; Ogundiwin et al., 2015; Jongsermtrakoon, 2015; Pitoyo et al., 2014; Kibbos and Tanui, 2013; Adora, 2014) only reveals the effect of its implementation on learning outcomes, motivation, collaboration, and creative thinking. Meanwhile, research on the implementation of the group investigation model of science process skills is still very limited. Therefore this study was conducted to determine the effectiveness of the application of the learning model of group investigation in improving students' science process skills and critical thinking abilities.

\section{RESEARCH METHODOLOGY}

This research used an experiment method with group control of pretest and posttest design (Gall et al., 2003). The details of the research design can be seen in Table 1.

Table1. Pretest-posttest Control Group Design

\begin{tabular}{|c|l|c|c|c|}
\hline Sample & Groups & Pretest & Treatments & Posttest \\
\hline Random & Experimental & $\mathrm{O}_{1}$ & $\mathrm{P}_{1}$ & $\mathrm{O}_{2}$ \\
\hline Random & Control & $\mathrm{O}_{3}$ & $\mathrm{P}_{2}$ & $\mathrm{O}_{4}$ \\
\hline
\end{tabular}

Information:

O1: Pretest before treatment is given to experimental group

$\mathrm{O}_{2}$ : Posttest after treatment is given to experimental group

O3: Pretest before treatment is given to control group

O4: Posttest after treatment is given to control group

$P_{1}$ : Treatment to experimental group

P2: Conventional learning method

The study involved $126 \mathrm{XI}$-grade Senior High School students who were divided into experimental and control groups. The experimental group consisted of 58 students while the control group consisted of 68 students chosen at random. Learning in the experimental group is carried out through a group investigation model, while the control group uses a conventional learning model. The study was conducted for two months, from November to January 2020 in one of the Senior High Schools in Meulaboh.

The parameters measured in data collection are science process skills and critical thinking abilities. Science process skills are measured using multiple-choice tests with four answer choices with several indicators such as observation skills, classifying skills, hypothesizing skills, communication skills, and interpreting skills (Feizioglu, 2009). Critical thinking ability is measured by an essay that has six indicators, namely focus, reason, inference, situation, clarity, and overview (Hapsari, 2016). Both data (critical thinking abilities and science process skills) are obtained through the pretest and posttest. 


\section{DATA ANANALYSIS}

Data on science process skills and critical thinking abilities are analyzed by a parametric analysis which includes tests of normality, homogeneity, normalized gain (n-gain), and two-difference test. Two different test averages are carried out using independent sample t-tests by comparing the initial ability (the results of the pretest) with the final ability (n-gain).

\section{FINDINGSANDDISCUSSION}

\subsection{Improving Science Process Skill}

Figure 1 shows the science process skill data in the experimental and control groups. The data show that the average of the post-test and n-gain group of the experimental and control group is higher than the average of the pretest data. The initial ability of students before treatment showed no significant difference between the experimental and control groups. While the increase in science process skills showed significantly different results (Table-1). This difference shows that the application of the group investigation learning model has a significant effect on the improvement of the science process skills of the experimental group students compared to the control group.

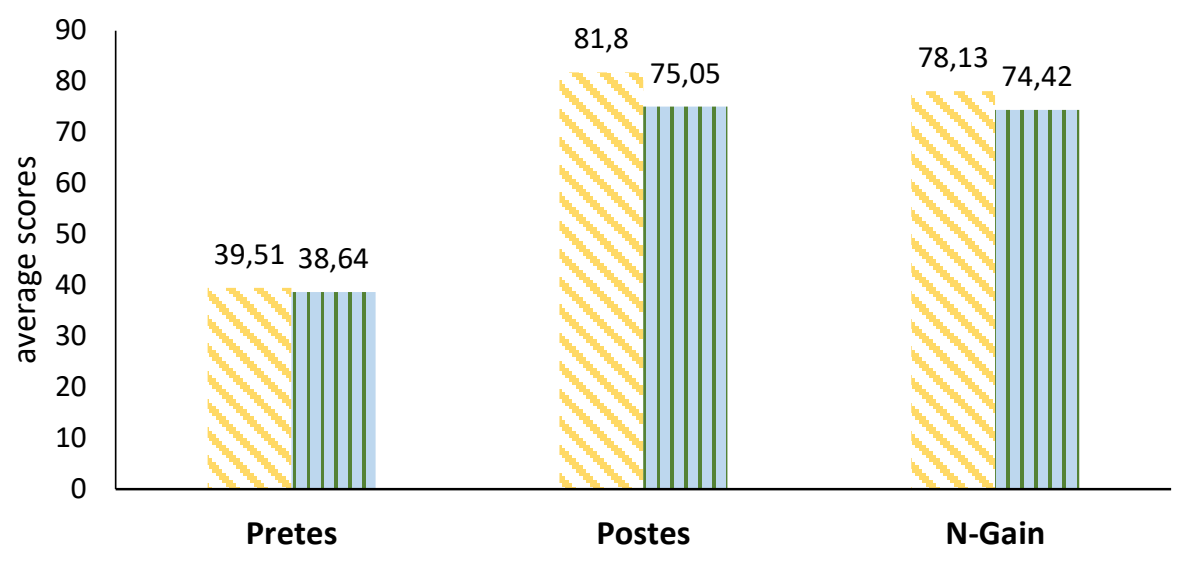

Eksperimen Kontrol

Figure-1. The average score of the results of the pretest, posttest, and $n$-gain

The application of the group investigation learning model was proven to be able to improve the science process skills of the experimental group students. The group investigation learning model provides opportunities for students to conduct scientific investigations by observing, asking, analyzing, concluding, and communicating. Improved science process skills are also caused by discussions in learning that can develop students' cognitive abilities. Besides, the application of the group investigation learning model also allows students to appreciate the process of discovery or conceptualization (Sagala, 2009).

Table 1. Recapitulation of Pretest and N-Gain average difference tests on students' science process skills

\begin{tabular}{|c|c|c|c|c|c|}
\hline $\begin{array}{l}\text { Learning } \\
\text { outcome }\end{array}$ & Group & Normality & Homogeneity & $\mathrm{t}$-Test & Description \\
\hline \multirow{2}{*}{ Pretest } & Experiment & $\begin{array}{c}X^{2} \text { hit }(3,31)<X^{2} \text { tab } \\
(9,49) \text { (Normal) }\end{array}$ & \multirow{2}{*}{$\begin{array}{c}F_{\text {hit }}(1,36)<F_{\text {tab }} \\
(1,51) \\
\text { Homogeneous }\end{array}$} & \multirow{2}{*}{$\begin{array}{l}t_{\text {hit }}(0,59)< \\
t_{\text {table }}(1,97)\end{array}$} & \multirow{2}{*}{$\begin{array}{l}\text { No Significantly } \\
\text { Different }\end{array}$} \\
\hline & Control & $\begin{array}{c}X^{2} \text { hit }(6,38)<X^{2} \text { tab } \\
(9,49)(\text { Normal) }\end{array}$ & & & \\
\hline \multirow{2}{*}{ N-Gain } & Experimental & $\begin{array}{c}X^{2} \text { hit }\left(8,16<X^{2} \text { tab }\right. \\
(9,49) \text { Normal) }\end{array}$ & \multirow{2}{*}{$\begin{array}{c}F_{\text {hit }}(1,29)<F_{\text {tab }} \\
(1,53) \\
\text { Homogeneous }\end{array}$} & \multirow{2}{*}{$\begin{array}{l}t_{\text {hi }}(2,57)> \\
t_{\text {table }}(1,97)\end{array}$} & \multirow[b]{2}{*}{$\begin{array}{l}\text { Significantly } \\
\text { Different }\end{array}$} \\
\hline & Control & $\begin{array}{c}X^{2} \text { hit }(5,17)<X^{2} \text { tab } \\
(9,49) \text { (Normal) }\end{array}$ & & & \\
\hline
\end{tabular}

Description:

${ }^{*}$ squared test (Normal: $\left.\mathrm{X}_{\text {count }}^{2}<\mathrm{X}_{\text {table }}^{2} ; \alpha=0,05\right)$

${ }^{* *} \mathrm{~F}$ test (Homogeneous: $\mathrm{F}_{\text {count }}<\mathrm{F}_{\text {table }} ; \alpha=0,05$ )

The significance test results show that the group investigation learning model contributes to the improvement of science process skills. The results of the study of Parinduri et al. (2017) revealed that the implementation of the group investigation learning model improves and integrates students' thinking abilities. The application of group investigation also allows students to think analytically that makes them able to analyze data, 
distinguish phenomena, make conclusions, predict events, detail, describe, look for relationships, and evaluate general conclusions based on investigations that lead to the improvement of their science process skills (Arinda et al., 2019).

\subsection{Improving Critical Thinking Ability}

Figure-2 displays the data of critical thinking abilities of the experimental and control group students. The average post-test and $n$-Gain experimental and control groups were higher than the average pretest data. The initial ability of students before treatment did not show a real difference between the experimental and control groups. Increased critical thinking abilities (n-Gain) showed significantly different results (Table-2). This difference indicates that the application of the group investigation learning model in the experimental group has a significant effect on increasing student ability.

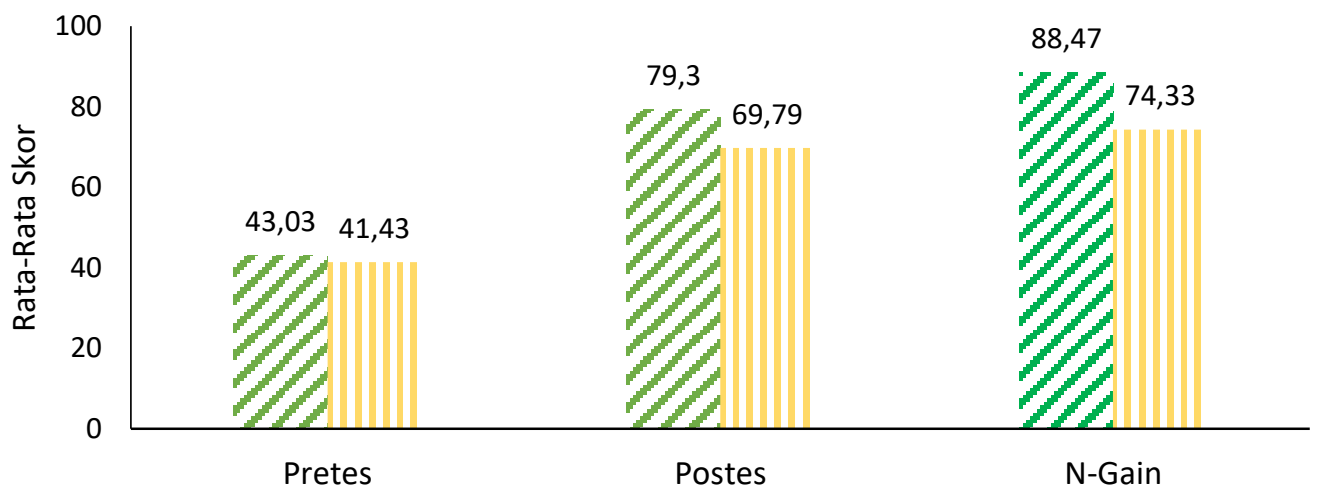

I Eksperimen || Kontrol

Figure-2. Skor Rata-Rata Pretest, Postest dan N-Gain Kemampuan Bepiir Kritis

Increased critical thinking abilities ( $n$-Gain) showed significantly different results (Table-2). This difference is caused by the application of the group investigation model in the experimental group. The difference between $n$-gain of critical thinking ability between the experimental group and the control group was $14.14 \%$ (Figure-2). It shows that the application of the group investigation learning model positively contributes to the increase in students' critical thinking ability in the experimental group.

The group investigation model focuses on the learning activities of students. It allows students to use their knowledge in finding answers to their investigations (Santyasaet at al., 2018). This learning model can also increase learning interest, curiosity, and responsibility for whatever they do.

Table 2. Recapitulation of Pretest and N-Gain Average Difference on Students' Critical thinking abilities

\begin{tabular}{|c|c|c|c|c|c|}
\hline $\begin{array}{l}\text { Learning } \\
\text { outcome }\end{array}$ & Group & Normality & Homogeneity & $t$ Test & Description \\
\hline \multirow{2}{*}{ Pretest } & Experimental & $\begin{array}{c}X^{2} \text { hit }(6,43)<X^{2} \text { tab } \\
(9,49) \text { (Normal) }\end{array}$ & \multirow{2}{*}{$\begin{array}{c}F_{\text {hit }}(1,08)<F_{\text {tab }} \\
\quad(1,51) \\
\text { Homogeneous }\end{array}$} & \multirow{2}{*}{$\begin{array}{l}t_{\text {hit }}(0,70)< \\
t_{\text {table }}(1,97)\end{array}$} & \multirow{2}{*}{$\begin{array}{l}\text { Not significantly } \\
\text { different }\end{array}$} \\
\hline & Control & $\begin{array}{c}X^{2} \text { hit }(7,14)<X^{2} \text { tab } \\
(9,49) \text { (Normal) }\end{array}$ & & & \\
\hline \multirow{2}{*}{ N-Gain } & Experimental & $\begin{array}{c}X^{2} \text { hit }\left(5,03<X^{2} \text { tab }\right. \\
(9,49) \text { Normal })\end{array}$ & \multirow{2}{*}{$\begin{array}{c}F_{\text {hit }}(1,47)<F_{\text {tab }} \\
(1,51) \text { Homogeneous }\end{array}$} & \multirow{2}{*}{$\begin{array}{l}\mathrm{t}_{\text {hit }}(8,68)> \\
\mathrm{t}_{\text {table }}(1,97)\end{array}$} & \multirow{2}{*}{$\begin{array}{l}\text { Significantly } \\
\text { different }\end{array}$} \\
\hline & Control & $\begin{array}{l}X^{2} \text { hit }(5,47)<X^{2} \text { tab } \\
(9,49) \text { (Normal) }\end{array}$ & & & \\
\hline
\end{tabular}

Description:

* Squared test (Normal: $\mathrm{X}_{\text {count }}^{2}<\mathrm{X}_{\text {table } ; \alpha=0,05)}^{2}$

${ }^{* *} \mathrm{~F}$ test (Homogeneous: $\mathrm{F}_{\text {count }}<\mathrm{F}_{\text {table }} ; \alpha=0,05$ )

Increasing students' critical thinking abilities in learning the group investigation model is triggered by demands for exploring various problems, collecting relevant data, developing and testing hypotheses. Those demands indirectly train students to build the ability to think independently and critically and solve problems in groups (Sumarmi, 2012). Duran and Sendag (2012) also stated that the application of the group 
investigation model can improve critical thinking abilities because students are required to actively participate in determining topics, investigating problems, and analyzing and presenting findings. The model can also increase student activity and participation to search for material (information) independently from various sources (relevant books or the internet). Reading various references can increase students' knowledge and encourage them to think critically (Kenderee et al., 2012).

Significance test results show that group investigation contributed positively to increasing critical thinking ability. The results of the Limbach and Waugh study (2007) showed that critical thinking abilities can be improved by allowing students to ask questions, submit ideas, and discuss. This research shows that students are actively discussing to plan research, conduct an investigation of the problems found, and consult with the teacher regarding the preparation of reports. Students also actively ask questions and discuss them at the presentation stage. Then in the evaluation phase, students conclude what they learn based on the results of the investigation and other supporting sources.

Research conducted by Lawson (2001) also showed that group investigation learning influences students' critical thinking abilities. The learning model has a learning syntax that supports the realization of a scientific approach that requires students to use high-level thinking skills. Chaplin's (2007) research also revealed that students' ability to think critically and solve problems must be preceded by their active role in identifying or formulating questions, organizing thoughts, paying attention to similarities and differences, making deductions, and determining the validity of a conclusion. The group investigation learning model allows students to formulate questions based on phenomena that have been presented by the teacher and choose subtopics in the investigation process.

\section{RERERENCE LIST}

Adora, N.M. 2014. Group Investigation in Teaching Elementary Science. International Journal of Humanities and Menagement Science, 2(3):2320-4044.

Arinda, Y.; Wilujeng, I \& Kuswanto, H. 2019. The Application Group Investigation (GI) Learning Model Assisted Phet to Facilitate Student Scientific Work Skills. International Journal of Educational Research Review, 4(2): 254-261.

Chaplin, S. 2007. A Model of Student Succes: Coaching Students to Develop Critical Thinking Skills in Introductory Biology Course. International Journal for the Scholarship of Teaching and Learning, 1(2):1-7.

Duran, M., \& Sendag, S. 2012. A Pleminary Investigation into Critical Thinking Skills of Urban High School Students: Role of an IT/STEM Program. Creative Education, 3(2):241-250.

Eggen \& Kouchak. 2012. Srategi dan Model Pembelajaran. Jakarta: PT Indeks.

Feizioglu, B. 2009. An Investigation of Relationship between Science Process Skills with Efficient Laboratory Use and Science Achievement in Chemistry Education. Journal of Turkish Science Education, 6(11):115-132.

Gall, M. D.; Gall,J.P \& Brog, W.R. 2003. Educational Research An Introduction Boston: Pearson Education Inc.

Handayani, S. L.; Suciati. \& Marjono. 2016. Peningkatan Keterampilan Proses pada Pembelajaran Biologi Melalui Penerapan Model Bounded Inquiry Lab. Bioedukasi. 9(2):49-54.

Hapsari, S. 2016. Descriptive Study Of The Critical Thinking Skill Of Social Science at Junior High School. Journal Of Education and Learning, 10(3): 228-234.

Johnson, D. W; Johnson, R.T \& Smith, K. 2007. The State of Cooperative Learning in Postecondary and Professional Settings. Educational Psychology Review, 19(1): 15-29.

Jongsermtrakoon, S. 2015. A Group Investigation Learning System for Open Educational Resources to Enhance Student Teachers'Digital Literacy and Awerennes in Information Ethics. International Journal of Information and Education Technology, 5(10):56-68.

Kenderee, J.; Small, C \& Stenning, K. 2012. The Role of Representation in Teaching and Learning Critical Thingking. Educational Review, 54(1):57-67. 
Kibbos, J.K \& Tanui , E.K. 2013. Effectiveness of e-Learning Investigation Model on Students's Uderstanding of Classification of Organism in School Biology. Journal of Education and Practise, 4(7):1-11.

Lawson, A.F. W. 2001. Promoting Creative and Critical Thinking Skills in College Biology. Bioscenes, 27(1):13-23.

Limbach, B. \& Waugh, W. 2007. Developing Higher Level Thinking. Journal of Instructional Pedagogies, 2(1):1-9.

Linuhung, N \&Sudarman. 2016. Pengaruh Pembelajaran Kooperatif Tipe Group Investigation (GI) terhadap Kemampuan Penalaran Matematis Siswa Mts. Jurnal Pendidikan Matematika, 5(1):52-60.

Mitchell, M.G.; Holder, M.; Montgomery, H \& Stuart. 2008. Group Investigation as a Cooperative Learning Strategy: An Integrated Analysis of the Literature. The Alberta Journal of Education Research, 54(4):16-28.

Nugraha, A. J.; Suyitno, H. \& Susilaningsih, E. 2017. Analisis Kemampuan Berpikir Kritis Ditinjau dari Science process skill Peserta dan Motivasi Belajar Melalui Model PBL. Journal of Primary Education, 6(1):35-43.

Ogundiwin, O. A.; Asaaju, O. A.; Adegoke, A.L \& Ojo, A. T. 2015. Effect of Group Investigation Laboratory Strategies on Students Achievment in Biology. Pyrex Journal of Research in Environmental Studies, 2(4): 35-41.

Parinduri, S. P.; Makmur, \& Ridwan, A, S. 2017. The Effect of Cooperative Learning Model Type Group Investigation for Student's Conceptual Knowledge and Science Process Skills. Journal of Research \& Method in Education, 7(4):38-46.

Pitoyo, A.; Waluyo, H. J.; Suwandi, S.\& Andaryani. 2014. The Effect of Group Investigation Learning, Model, Accelerated Learning Team and Role Playing on Elementary School Students' Writing Skills Viewed from Cognitive Style. Journal of Education and Practice,5(1):21-29

Sagala, S. 2009. Konsep dan Makna Pembelajaran. Bandung: Alfabeta.

Santyasa, W.; Sudarma, K.\& Warpala, W. K. 2018. The Power of Group Investigation Model on Student Critical Thinking, Attitude and Character in Learning Physics. Advances in Social Science Education and Humanities Research, 27(4):101-106.

Siddiqui, M. H. 2013. Group Investigation Model of Teaching: Enhancing Learning Level. Indian Journal of Research, 3(4):78-80.

Suhartono.; Degeng, N.S.; Suyitno \& Sulton. 2019. A Comparison Study: Effects of the Group Investigation Model and the Direct Intruction Model Toward Science Concept Understanding. Jurnal Pendidikan IPA Indonesia, 8(2):185-192.

Sumarmi. 2012. Model-Model Pembelajaran Geografi. Malang: Aditya Media

Tsoi, M.F., Goh, N.K., \& Chia, L.S. 2004. Using group investigation for chemistry in teacher education. AsiaPacific forum on science teaching and learning, 5(1):11-25. 